\title{
NUANSA KOTA KOLONIAL SURAKARTA AWAL ABAD XX: FASE HILANGNYA IDENTITAS LOKAL
}

\author{
Susanto \\ Program Studi Sejarah Fakultas Ilmu Budaya \\ Universitas Sebelas Maret
}

Alamat korespondensi: santosastrauns@yahoo.co.id

Diterima/ Received: 12 Januari 2016; Disetujui/ Accepted: 22 Februari 2016

\begin{abstract}
This article examines changes of Surakarta outlook in the early twentieth century. Surakarta was originally an Indis city, since the beginning of the XX century it progressed toward a colonial city. Based on the Dutch official reports in Surakarta, contemporary newspapers, and secondary sources, the city changes began with increasing number of Dutch female immigrants who came and settled at the city. They established nuclear families via marriage with fellow Dutchmen, so that the Dutch European community at Surakarta became stronger and more established. It was strengthened by the government's confidence to intervene financial affairs in Javanese palaces and overhaul traditional structures by government reorganization and agrarian affairs. The government also implemented canonization policy in law, education, and culture. This policy was originally intended to implements European values in the Indies. However, in the policy development turned out to spawned a colonial society that was soon followed by the erosion of identity as Indis city. The canonization policy also impacted on the changing patterns of intercommunity relations manifested in multi-discriminatory practices at various domains, that harassed and degraded the Indo community, especially the indigenous community. Both of them then were rediscovered their identity order.
\end{abstract}

Keywords: Indis; Canonization; Politic identity; Surakarta

\section{Abstrak}

Artikel ini membahas tentang perubahan wajah Surakarta pada awal abad XX. Surakarta semula merupakan sebuah kota Indis, tetapi sejak awal abad itu memperlihatkan perkembangan menuju kota yang cenderung bercorak kolonial. Berdasar penelusuran historis melalui pemanfaatan laporan-laporan pejabat Belanda di Surakarta, surat kabar-surat kabar sezaman, dan sumber-sumber sekunder diketahui bahwa perubahan itu dimulai seiring dengan semakin banyaknya imigran wanita Belanda yang datang dan menetap di Surakarta. Mereka membentuk keluarga inti melalui perkawinan dengan sesama orang Belanda, sehingga kedudukan komunitas Eropa Belanda di Surakarta menjadi semakin kuat dan mapan. Hal ini memperkuat kepercayaan diri pemerintah untuk melakukan campur tangan dalam urusan keuangan di istana-istana Jawa dan merombak struktur tradisional melalui reorganisasi pemerintahan dan agraria. Pemerintah kemudian juga menerapkan kebijakan kanonisasi di bidang hukum, pendidikan, dan budaya. Kebijakan ini pada awalnya bertujuan untuk menerapkan nilai-nilai Eropa di Hindia Belanda. Akan tetapi, dalam perkembangan kebijakan itu ternyata telah melahirkan masyarakat kolonial yang segera diikuti dengan tergerusnya identitas Surakarta sebagai kota Indis. Kebijakan kanonisasi itu juga berdampak pada terjadinya perubahan pola relasi antarkomunitas yang mewujud dalam berbagai praktik diskriminatif di berbagai ranah, yang melecehkan dan merendahkan komunitas Indo maupun terutama pribumi Jawa. Kedua komunitas ini kemudian mengambil langkah-langkah untuk menemukan kembali identitas mereka yang telah terkikis.

Kata Kunci: Indis; Kanonisasi; Politik identitas; Surakarta 


\section{PENDAHULUAN}

Masyarakat Indis di Surakarta sejak 1871 semakin berkembang. Hal itu ditandai dengan banyaknya pendatang baru kaum kulit putih seiring dengan berkembangnya praktik sewa tanah di wilayah kerajaan. Untuk memperkuat usaha perkebunan, mereka membentuk sebuah komunitas usaha yang diberi nama Solosche Landhuurder Vereeniging. Bersamaan dengan keberadaan kaum penyewa tanah ini berkembang berbagai fasilitas seperti bank, sekolah, alat transportasi dan komunikasi, dan sarana hiburan. Kemajuan yang menakjubkan ini membuat Surakarta berkembang menjadi kota Indis baru yang berbeda secara signifikan dari periode sebelumnya.

Memasuki abad XX, Surakarta yang mampu mempertahankan hybrid culture semakin menarik minat para pendatang dari Eropa untuk datang dan menetap. Kedatangan mereka tidak terhindarkan mengingat Surakarta termasuk enam kota besar di Jawa. Namun demikian, keberadaan komunitas kulit putih baru ini kurang mampu mendinamisasi budaya Indis. Mereka justru mendorong munculnya budaya baru melalui praktik kanonisasi budaya. Selain menyimpang dari semangat hybrid culture Indis, praktik ini menciptakan masyarakat baru, yaitu masyarakat kolonial, yang akhirnya mengundang reaksi dari komunitas-komunitas lain yang terkena dampak negatifnya.

Dalam hubungan itu, dalam artikel ini akan dibahas mengenai proses kedatangan orang Eropa totok di Surakarta pada awal abad XX, munculnya masyarakat kolonial, reaksi terhadap kanonisasi budaya, dan akhir konflik yang menunjukkan kecenderungan ke arah baru dalam hubungan antarkomunitas di Surakarta.

\section{PENDATANG BARU}

Perubahan sosial ekonomi pada seperempat terakhir abad XIX telah meletakkan dasar bagi munculnya masyarakat baru di Hindia Belanda baik di Jawa maupun pulau-pulau besar lainnya. Hal ini tampak dari munculnya sebuah fenomena yang menarik yaitu meningkatnya jumlah imigran Eropa.
Dalam sebuah catatan kependudukan dinyatakan bahwa imigran Eropa yang menetap di Hindia Belanda pada dasawarsa pertama abad XIX lebih banyak dibandingkan dengan sebelumnya ketika migrasi terjadi semata-mata melalui aktivitas perdagangan. Para imigran membentuk keluarga sehingga tingkat pertumbuhan mereka lebih besar dibandingkan pendatang asing lainnya yang tidak menetap. Besarnya kelompok inti dari pendatang yang menetap itu diketahui dari bertambahnya jumlah wanita dalam kelompok asing. Pada orang Eropa, jumlah wanita dalam setiap 1000 jiwa pria sangat meningkat; dan pada 1930 jumlah mereka lebih tinggi dibandingkan dengan yang ada pada kelompok penduduk asing lainnya. Hal itu selain disebabkan oleh bertambahnya orang Eropa yang menetap, juga karena jumlah imigran wanita Eropa sejak 1900 terus meningkat (Creutzberg, 1987: 34-35). Peningkatan jumlah wanita asing di Hindia Belanda dapat dilihat dalam tabel berikut.

Tabel 1. Pertumbuhan Penduduk Asing di Hindia Belanda, 1860-1930

\begin{tabular}{crrr}
\hline Tahun & Eropa & Cina & Arab \\
\hline 1860 & 43.876 & 221.348 & 8.909 \\
1880 & 59.903 & 343.793 & 16.025 \\
1900 & 91.142 & 537.316 & 27.399 \\
1905 & 94.518 & 563.449 & 29.588 \\
1920 & 168.114 & 809.039 & 44.902 \\
1930 & 240.417 & 1.233 .214 & 71.335 \\
\hline
\end{tabular}

Sumber: Creutzberg, 1987.

Tabel 2. Jumlah Wanita Asing setiap 1000 Penduduk

\begin{tabular}{cccc}
\hline Tahun & Eropa & Cina & Arab \\
\hline 1860 & & 590 & 809 \\
1880 & 481 & 620 & 830 \\
1900 & 636 & 548 & 857 \\
1905 & 672 & 526 & 890 \\
1920 & 800 & 563 & 865 \\
1930 & 884 & 646 & 841 \\
\hline
\end{tabular}

Sumber: Creutzberg, 1987.

Jumlah komunitas kulit putih baru pada awal abad XX juga meningkat karena Surakarta termasuk salah satu dari enam kota besar di Jawa. ${ }^{1}$ Gambaran mereka di Surakarta dapat dilihat pada tabel di bawah ini, yang merupakan 
perbandingan antara jumlah pada 1905 dan 1917.

Tabel 3. Perbandingan Jumlah Penduduk pada 1905 dan 1917.

\begin{tabular}{lrrrrrr}
\cline { 2 - 7 } Daerah & Eropa & Pribumi & Cina & Arab & $\begin{array}{l}\text { Asing } \\
\text { lain }\end{array}$ & Jumlah \\
\hline Surakarta & 1572 & 109524 & 6532 & 337 & 413 & 118378 \\
Klaten & 267 & 6949 & 982 & - & 4 & 8209 \\
Boyolali & 157 & 5522 & 446 & - & - & 6125 \\
Sragen & 69 & 7463 & 334 & - & - & 7963 \\
Wonogiri & 4 & 1475 & 334 & - & - & 1813 \\
\hline
\end{tabular}

Sumber: Regeering Almanak voor

Nederlandsch-Indie, 1915.

Tabel 4. Jumlah Penduduk Surakarta 1917

\begin{tabular}{lrrrr}
\hline & \multicolumn{4}{c}{ Golongan Penduduk } \\
\cline { 2 - 5 } Daerah & Eropa & Timur & Pribumi & Jumlah \\
& \multicolumn{4}{c}{ Asing } \\
Surakarta & 2000 & 10104 & 898328 & 910432 \\
Klaten & 1145 & 2295 & 483860 & 487300 \\
Boyolali & 408 & 474 & 291842 & 292724 \\
Sragen & 366 & 1124 & 368924 & 370414 \\
\hline
\end{tabular}

Sumber: Regeering Almanak voor

Nederlandsch-Indie, 1921.

Menjelang akhir abad XIX terjadi perubahan besar. Jumlah orang Eropa dan yang dipersamakan dengan mereka meningkat sampai $33,4 \%$ di Jawa dan Madura pada periode 18931905. Pada 15 tahun berikutnya (1905-1920), jumlah penduduk meningkat $108 \%$ atau empat kali lipat (Data ini hanya menyangkut warga Eropa. Pada 1893 jumlah mereka di Jawa dan Madura adalah 48.649 orang, pada 1905 sebanyak 64.917 orang, dan pada 1920 sebanyak 135.288 orang. Angka-angka untuk 1905 kiranya kurang terpercaya, sedangkan batas kesalahan untuk sensus pada 1920 adalah $5 \%$ ).

Eropanisasi koloni perlahan-lahan mengakhiri budaya bujang. Perkawinan para pejabat dan orang swasta semakin banyak terjadi setelah pencabutan larangan yang berlaku bagi kalangan totok pada abad XIX. Izin masuk bagi wanita Belanda ke Hindia yang menyertainya memiliki pengaruh yang menentukan pada pemandangan kota karena mereka tetap berpegang teguh pada cara hidup dari lingkungan Belanda. Di kota-kota besar, seluruh kampung telah memutuskan hubungan dengan gaya bangunan tropis lama, sehingga rumah- rumah itu semakin mirip dengan rumah-rumah di pedesaan Belanda.

Keberadaan para wanita Belanda yang tetap mempertahankan cara hidup lama membuat mereka lebih sensitif. Mereka juga mengalami kesulitan dalam menyesuaikan diri dengan gaya hidup Indis di lingkungan yang baru. Di Surakarta mereka merasakan sensitivitasnya dalam "insiden Habiprojo" pada 1904. Insiden ini menunjukkan keterkejutan komunitas Eropa terhadap pribumi. Keterkejutan itu dirasakan ketika sejumlah wanita Eropa yang sedang mendampingi suami mereka berkunjung ke Habiprojo, sebuah klub para priyayi Jawa. Klub ini tidak pernah dihadiri oleh kaum wanita Jawa sekalipun. Tanpa diduga, seorang wanita Eropa merasa dilecehkan ketika seorang lelaki Jawa tiba-tiba datang dan menawarkan untuk menemaninya. Pada satu sisi para wanita Belanda dianggap melakukan suatu yang tidak biasa karena mereka telah memasuki area lakilaki Jawa. Akan tetapi, pada sisi yang lain, sikap laki-laki Jawa itu menunjukkan kekhawatiran yang mendalam terhadap hubungan antarras dan prestise Eropa (Taylor, 2009: 302).

Insiden Habiprojo tidak hanya mengejutkan imigran baru Eropa pada awal abad XX, tetapi secara langsung juga telah menciderai budaya dan masyarakat Indis. Insiden itu sesungguhnya dipicu oleh penyimpangan lain yang terjadi sebelumnya. Kejadian yang mengejutkan dan disesalkan ialah pembunuhan yang dilakukan oleh orang pribumi terhadap keluarga Indo bernama O.E. Sivaving pada 15 Januari 1886. Dalam kasus ini, isteri dan mertua korban ikut disalahkan (ANRI, Algemeen Verslag van Residentie Soerakarta over het jaar 1886 No. 388). Sebuah laporan pemerintah juga menyebutkan adanya Gerakan Srikaton yang mengguncang masyarakat Indis Surakarta. Pemerintah khawatir karena gerakan ini menyebarkan ilmu kebal yang menyertai beredarnya ramalan akan adanya suatu perang besar dalam waktu dekat dan suatu pemberontakan untuk menggulingkan penguasa, yang diikuti dengan berdirinya sebuah kerajaan Islam yang baru. Di kerajaan ini tidak ada kaum kafir dan orang yang tidak mematuhi ajaran baru akan dihukum mati. Oleh karena itu, setiap 
orang harus memakai azimat dan tanda-tanda khusus agar dapat dikenali sebagai pengikut kerajaan baru. Gerakan ini dipimpin oleh Kertodrono yang dalam posisinya sebagai wali dikenal sebagai Imam Sampurno. Gerakan Srikaton muncul beberapa bulan setelah Peristiwa Cilegon pada Juli 1888. Sepak terjang kelompok Imam Sampurno telah menimbulkan ketakutan dan dianggap berbahaya oleh istana Mangkunegaran karena mereka melakukan aksi kesurupan pada malam hari di Pesanggrahan Srikaton, Tawangmangu. Huru-hara Imam Sampurno tidak berlangsung lama. Pada pukul 9 pagi 12 Oktober 1888 mereka sudah dapat ditumpas oleh pasukan Legiun Mangkunegaran. Pemimpin gerakan yaitu Imam Sampurno tewas tertembak. Dalam aksi penumpasan itu ikut pula Pangeran Mangkunegara $\mathrm{V}$ dan Residen Surakarta A.J. Spaan. ${ }^{2}$ Oleh karena dianggap telah membawa sial, Mangkunegara V memerintahkan agar bangunan Pesanggrahan Srikaton dirobohkan hingga rata dengan tanah dan hanya disisakan bagian lantainya (Sordrager, 1936: 46).

Akibat dari insiden-insiden itu selanjutnya menimbulkan babak baru dalam hubungan antarkomunitas di Surakarta. Kemudian diketahui bahwa akhirnya tata krama Mestizo tidak lagi menjadi pedoman untuk mengatur perilaku masyarakat pada dekade kedua dan ketiga abad XX. Pada saat itu masyarakat imigran terkelompok di kota-kota dalam jumlah yang cukup untuk menjalankan gaya hidup mereka sedekat mungkin dengan gaya hidup Belanda. Secara kebetulan pada 1908 diterbitkan sebuah buku pedoman bagi para wanita muda dari Eropa yang menikah. Buku yang berjudul Ons Huis in Indie ini memuat hal-hal yang perlu diketahui oleh kaum wanita Eropa tentang pakaian, makanan, dan perawatan di lingkungan yang cuaca dan budayanya asing bagi mereka. Nasihat dalam buku pedoman ini menunjukkan bahwa cara hidup orang Belanda telah banyak ditanamkan dalam masyarakat Hindia.

Nasihat dalam buku itu khususnya yang berkaitan dengan penggunaan pakaian dan gaya rumah baru tampaknya telah menunjukkan arah perubahan penting di Hindia. Dalam buku itu disebutkan bahwa orang Eropa yang cara berpakaiannya mengikuti pribumi bertentangan dengan peradaban Barat. Menurut cara pandang Barat, pakaian pribumi seperti sarung dan kebaya hanya layak dipakai oleh orang yang sedang sakit. Pakaian semacam itu juga mencerminkan sifat malas pemakainya. Orang Belanda moderen tidak pantas memakai pakaian Hindia terutama ketika mereka berada di serambi depan rumah moderen, kecuali jika hal itu dilakukan di daerah pedalaman yang jauh dari peradaban. Nasihat lain adalah bahwa dalam konstruksi "rumah sehat Eropa”, ruang pembantu sedapat mungkin dipisahkan jauh dari bangunan inti, yaitu di bagian belakang yang terlepas dari area privat Eropa (gambaran detail pada Gambar 1). Kedua nasihat itu telah menunjukkan dengan jelas bahwa keramahtamahan masa lalu sebagai "warna Indis" di kota-kota besar Hindia telah meredup dan mulai digantikan oleh warna baru dengan cap baru pula yakni Belanda. Lebih jauh lagi diketahui bahwa walaupun imigran asli Eropa jauh lebih sedikit daripada jumlah seluruh orang Eropa yang tinggal Indonesia, imigran asli banyak memegang jabatan tinggi. Mereka juga menentukan selera dan mode seluruh masyarakat kolonial (Taylor, 2009: 302).

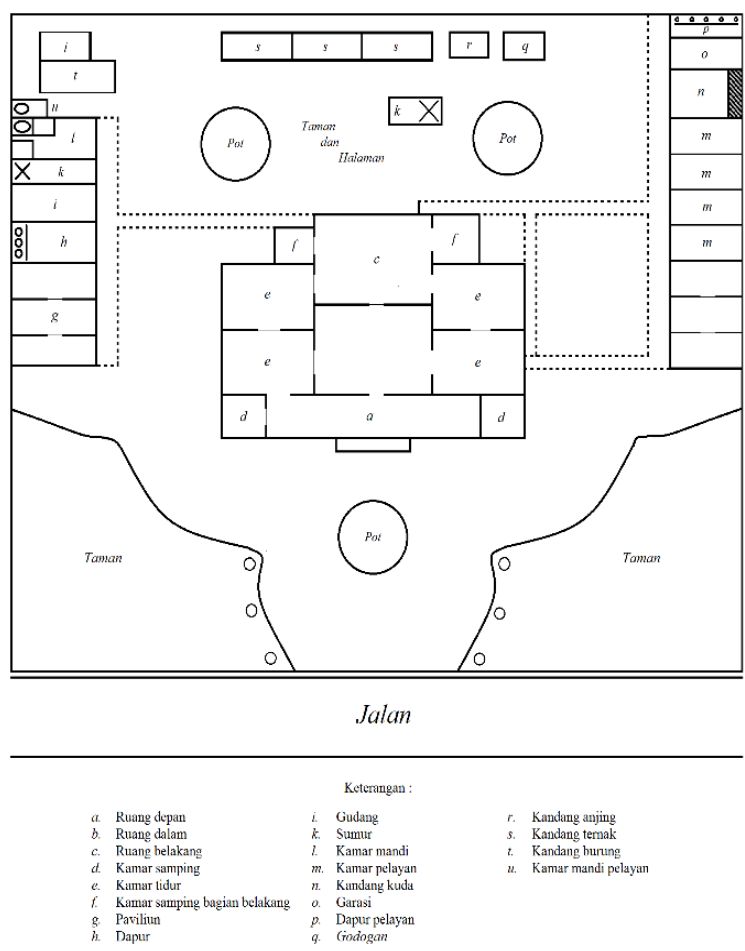

Gambar 1. Ons Huis in Indie: Wilayah bediende - pelayan jauh dari ruang utama.

Sumber: Catenius-van der Meijden, 1908. 
Dengan demikian tampak dua perkembangan penting, khususnya di Jawa, yang mengarah pada munculnya sebuah kota dengan wajah kolonial, yaitu Eropanisasi kota yang meningkat pesat pada sekitar pergantian abad dan pembaruan dalam pemerintahan dan pengaturan kota yang semakin mempercepat Eropanisasi dalam tata kota.

Eropanisasi berlangsung melalui penerapan kanonisasi di beberapa bidang. Bentuk kanonisasi yang paling nyata dirasakan di Surakarta terdapat di bidang hukum dan pendidikan. Kanonisasi di bidang hukum terwujud pada pengaruh yang dirasakan dalam sistem pemerintahan tradisional yang terjadi pada 1903 ketika pengadilan Belanda menggeser sistem pengadilan lokal. Berdasar kebijakan yang dituangkan dalam Staatsblad No. 71903 dan Staatsblad No. 8 1903, maka pengadilan tradisional seperti Pengadilan Balemangu, Pradata, dan Surambi yang berlaku di wilayah Keresidenan Surakarta diganti dengan pengadilan gubernemen atau Landraad. ${ }^{3}$ Dengan penerapan sistem pengadilan baru itu maka penurunan kewibawaan raja pun semakin terasa. Sebagai contoh, menurut peraturan lama Pengadilan Balemangu, siapa pun yang melakukan pelanggaran hukum di wilayah Surakarta termasuk dari kalangan Kumpeni harus diadili berdasar hukum lokal. ${ }^{4}$ Akan tetapi, sejak diberlakukan peraturan Staatsblad No. 8 1903, seluruh penduduk Surakarta yang melanggar hukum, baik orang Belanda maupun pribumi, harus diadili di pengadilan Belanda atau Landraad. ${ }^{5}$ Produk hukum lain yang menunjukkan tanda kanonisasi di Surakarta adalah peraturan tentang pembangunan rumah di dalam kota, peraturan tentang kepala desa, dan peraturan kepolisian. ${ }^{6}$

Di samping masalah hukum, terdapat indikasi adanya keinginan residen untuk campur tangan di bidang keuangan Keraton Surakarta. Indikasi ini tampak ketika Residen van Wijk melihat bahwa sangat penting bagi pemerintah untuk mengatur pembukuan keuangan keraton dengan cara Eropa. Hal ini telah dilakukan oleh Residen Couperus di Yogyakarta, yang melimpahkan tugas ini ke tangan asisten residen. Residen van Wijk melihat adanya kemungkinan untuk menerapkan cara itu pada Keraton Surakarta. Salah satu pertimbangannya adalah kebiasaan Sunan saat melakukan perjalanan yang selalu diikuti oleh rombongan yang besar. Diduga bahwa kebiasaan ini memerlukan biaya besar yang tentu akan berdampak buruk pada pengelolaan keuangan keraton. Tentu saja alasan van Wijk kurang masuk akal karena melakukan perjalanan bukan merupakan kebiasaan dari rajaraja pendahulu Paku Buwana $\mathrm{X}$ yang memandang bahwa hal itu kurang bermanfaat. Melihat laporan van Wijk, alasan politis tampaknya lebih dominan dibandingkan dengan asalan ekonomis. Kebiasaan Paku Buwana X melakukan perjalanan pada satu sisi dirasa memboroskan anggaran. Akan tetapi, pemerintah lebih mengkhawatirkan risiko politik dari kebiasaan itu, yaitu eksistenasi sunan sebagai raja Jawa akan semakin kuat. Oleh karena itu, van Wijk mengusulkan kepada Gubernur Jenderal agar kebiasaan itu segera diakhiri. Usul van Wijk tidak terlaksana sepenuhnya karena ia hanya berhasil mengurangi jumlah pengikut. Kebiasaan Sunan Paku Buwana $\mathrm{X}$ untuk mengadakan perjalanan dimulai pada masa Residen Vogel, yang dilakukan dengan membawa ratusan orang pengikut ketika berkunjung ke Semarang. Sesudahnya ditetapkan menjadi 200 orang, dan pada era van Wijk jumlah itu dikurangi lagi secara drastis menjadi 80 orang. Selanjutnya pada masa Residen Sollewijn Gelpke sunan diminta untuk tidak lagi membawa pengikut lebih dari 18 orang ketika melakukan perjalanan ke Bogor dan Bandung pada 1916. Kendati demikian, Gelpke mengakui bahwa kharisma sunan sebagai raja Jawa tetap kuat dalam perjalanan itu. ${ }^{7}$ Keinginan van Wijk untuk mengatur keuangan keraton hingga sedemikian jauh belum berhasil karena setiap pembicaraan mengenai pengelolaan keuangan keraton dengan cara Eropa selalu ditolak oleh sunan (Sordrager, 1936: 21). ${ }^{8}$

Namun demikian van Wijk setidaknya telah berhasil mengubah kebiasaan berupa tata cara saat patih menghadap di kantor residen, seperti yang diungkapkan dalam laporannya. Patih setiap Senin dan Rabu bersama semua rombongannya tampil di pagelaran keraton. Ada kebiasaan bahwa sekitar pukul setengah dua 
belas dia berangkat ke rumah residen untuk membicarakan persoalan dinas dengan residen. Karena saya menganggap dua kali terlalu banyak, saya meminta hanya hari Senin saja mereka datang. Pada tahun-tahun sebelumnya, patih hadir di pendopo yang berada di pekarangan residen, duduk di tanah sampai dia dipanggil. Ketika saya tiba, dia masih dilarang untuk memasuki tangga beranda depan, sesuatu yang diizinkan bagi orang Eropa rendahan atau juga kepada Letnan Cina. Saya telah mengakhiri larangan itu (MvO Van Wijk,1916: 18, 23)

Dampak kanonisasi yang paling berat dirasakan oleh elite tradisional di Surakarta adalah kebijakan reorganisasi khususnya di bidang agraria. Pada awalnya inisiator dari kebijakan ini tampak kabur. Dalam pertemuan di Majelis Rendah pada 1912, Menteri Urusan Jajahan de Waal Malefit menyatakan akan melakukan reorganisasi, yang telah didukung oleh sunan dan sultan. Sekalipun demikian beberapa sumber menunjukkan hal yang sebaliknya. Dalam berbagai laporan kolonial disebutkan bahwa tujuan utama reorganisasi itu adalah untuk merombak struktur keraton para raja pribumi sehingga pola pengelolaan keuangan, urusan rumah tangga, dan sistem perpajakan serta status hukum bagi individu pribumi sebanyak mungkin dapat sesuai dengan prinsip yang diterapkan oleh penguasa Barat. Selain itu, ada pandangan dari van Vollenhoven bahwa sistem apanage telah dianggap kurang menguntungkan bagi negara. Demi kemandirian negara, sistem itu harus dihapus.

Melihat kedua pernyataan di atas maka dapat dikatakan bahwa inisiatif untuk melakukan reorganisasi bukan berasal dari penguasa pribumi Jawa, melainkan dari penguasa Belanda yang ingin mendominasi atau bahkan menghapuskan hukum tradisional. Hal itu menjadi semakin jelas jika dilihat bahwa secara khusus tujuan reorganisasi agraria mencakup empat hal yaitu penghapusan apanage, pembentukan birokrasi desa, pemberian hak atas tanah yang lebih jelas kepada penduduk, dan pembaharuan sistem persewaan tanah.

Reorganisasi bidang agraria sudah dimulai pada 1905 meskipun penerapannya baru dimulai pada 1918. Menanggapi rencana reorganisasi dari pemerintah, pada November 1908 sunan mengirimkan surat kepada residen Surakarta tentang perlunya penyusunan sebuah peraturan sesuai dengan ketentuan dalam persewaan tanah-tanah pemerintah dan tentang penghapusan pemilikan apanage. Beberapa bulan kemudian Gubernur Jenderal van Heutz secara lisan memerintahkan kepada Residen van Wijk untuk mengajukan usul-usul yang diperlukan tentang reorganisasi setelah berunding dengan Direktur Pemerintahan S. de Graaff. Hal ini ditindaklanjuti dengan langkah nyata melalui kunjungan direktur pemerintah ke Surakarta pada Agustus 1909 guna membahas secara mendalam rencana reorganisasi agraria. Pada Mei 1910 gubernur jenderal mengirim Direktur Pemerintahan de Graaff ke Vorstenlanden untuk memberitahu para pengurus serikat pengusaha tentang rencana reorganisasi. Di Surakarta hal itu disampaikan pada 12 Mei 1910. Setelah informasi disampaikan kepada para penyewa tanah, selanjutnya gubernur jenderal pada 12 April 1912 secara resmi mengajukan permintaan kepada sunan untuk tidak lagi memperpanjang izin praktik sewa tanah lebih dari 10 tahun (MvO van Wijk, 1916: 39).

Pelaksanaan reorganisasi agraria di Surakarta selain menyita banyak waktu bagi residen, persiapannya juga dirasakan cukup melelahkan. Penerus van Wijk yaitu Sollewijn Gelpke sempat mengeluhkan hal ini.

“... waktu saya mulai bertugas pada 1914, Direktur Departemen Binnenlands Bestuur memberi tahu saya bahwa dalam beberapa bulan ordonasi itu sudah siap, namun ternyata ordonasi itu baru selesai pada 1918 (MvO Sollewijn Gelpke, 1918: 93)”

Dalam menjalankan tugas reorganisasi, Residen Gelpke dibantu oleh Asisten Residen H.A. Neys dan Controlleur J.P. Gulik. Kedua pembantu residen ini masing-masing mempunyai pembantu dua orang setingkat Adjunct Controlleur, sebuah kantor besar, dan mantri-mantri serta petugas lapangan. Tugas H.A. van Neys adalah membentuk dan mengelompokkan desa-desa serta membuatkan usul penetapan pajak bagi setiap perkebunan dan 
kawedanan. Sementara tugas van Gulik adalah memeriksa ladang-ladang percobaan dan penghapusan apanage ( $\mathrm{MvO}$, Sollewijn Gelpke, 1918: 94 )

Langkah awal dalam reorganisasi agraria ialah penghapusan apanage, yang di Surakarta meliputi wilayah Kasunanan maupun Mangkunegaran. Penghapusan apanage di wilayah Mangkunegaran tidak menemui kesulitan karena praktik ini pernah dilaksanakan pada $1862 .{ }^{8}$

Penghapusan apanage di wilayah Kasunanan meliputi afdeeling Klaten, Boyolali, Surakarta, dan Sragen. Menurut Rijksblad Soerakarta 1917 No. 15, daerah di afdeeling Klaten yang mengalami penghapusan apanage pertama kali terdiri atas Prambanan, Klaten, dan Jatinom. Selanjutnya, menurut Rijksblad Soerakarta 1917 No. 16, dilakukan penghapusan apanage di Distrik Beji dan Delanggu (Klaten), Ponggok dan Simo (Boyolali), dan Kartasura (Surakarta). Sementara itu, untuk wilayah afdeeling Surakarta dan beberapa daerah Boyolali yang diatur dalam Rijksblad Soerakarta 1917 No. 35 meliputi Surakarta, Grogol, Sawahan, Sukoharjo, Tawangsari termasuk Banyudono, Boyolali, Ampel (Boyolali) serta Kotagede dan Imogiri (Yogyakarta). ${ }^{9}$ Selanjutnya penghapusan apanage di wilayah Sragen meliputi daerah Sragen, Masaran, Gemolong, Gondang dan Gesi. ${ }^{10}$

Sejak 1 Januari 1918 semua tanah apanage di wilayah Keresidenan Surakarta telah dihapus. Dengan penghapusan ini maka jabatan bekel juga turut dihapuskan. Kemudian para bekas bekel ini memperoleh ganti rugi berupa bumi pituwas atau tanah pension. Sistem gaji ini berlaku bersamaan dengan langkah pembaharuan status tanah di Surakarta. Dalam pembaharuan disebutkan bahwa mengenai hak milik pribumi atas tanah diberikan kepada desa, sementara hak pakai atas tanah desa diserahkan kepada penduduk.

Dalam pelaksanaan reorganisasi pada 1921, kantor pengukuran telah mengukur satuansatuan desa di keresidenan seluas 747.583 bahu, termasuk penyelesaian pengukuran di wilayah Surakarta. Selain itu untuk wilayah desa yang disewa, dan untuk perkebunan, juga telah diukur dan dibuat peta konversi dalam ukuran bahu. Hal ini terlihat pada Prambanan dengan luas 2997 bahu, Gondangwinangun-Jogonalan 4700 bahu, Cokrotulung-Ngoreskopen $4276 \mathrm{bahu}$, Delanggu 4040 bahu; serta perkebunan Mangkunegaran yaitu Tasikmadu dan Triagan 14475 bahu dan Colomadu 3139 bahu ( MvO Harloff, 1922: 67-68).

Reorganisasi tanah di Surakarta selesai pada 1927 pada akhir masa pemerintahan Residen J.H. Nieuwenhuis. Selanjutnya diketahui bahwa bentuk kepemilikian tanah dan pekarangan bersifat komunal. Selain itu untuk wilayah di luar kota terdapat kebijakan berupa larangan pengalihan hak atas tanah kepada orang asing. Akan tetapi, larangan ini tidak berlaku untuk wilayah perkotaan seperti Solo, Klaten, Boyolali, Sragen, Wonogiri, dan Karanganyar.

Reorganisasi agraria telah menunjukkan superioritas komunitas kulit putih melalui kanonisasi hukum yang tidak mampu dihindari oleh penguasa pribumi di Surakarta. Hal ini telah mengakibatkan mereka kehilangan sebagian wibawa dan kendali atas wilayahnya. Pada sisi lain, pengaruh asing yang paling menimbulkan kegelisahan elite pribumi Jawa di Surakarta adalah isu akan dihapuskannya Vorstenlanden. ${ }^{11}$ Sudah barang tentu gejolak akan muncul pula di kalangan rakyat mengingat kuatnya hubungan patron-klien pada masyarakat tradisional Jawa.

Di bidang pendidikan, kanonisasi dirasakan menjadi beban bagi orang Jawa. Hal itu terkait dengan ditetapkannya bahasa Belanda dan Melayu sebagai bahasa baku di sekolah-sekolah. Pada awal abad XX kebijakan itu muncul dalam bentuk pembakuan penguasaan bahasa Belanda. Kebutuhan akan bahasa Belanda dalam pendidikan dan pekerjaan diikuti dengan kebijakan baru berupa penerapan standar ejaan berdasar bahasa Belanda. Melalui Besluit Directeur van Onderwijs 12 Januari 1918 No. 1119 telah ditetapkan aturan baru tentang penulisan bahasa-bahasa anak negeri di Hindia Belanda dengan huruf Belanda, dimulai dengan ejaan bahasa Melaju, Jawa, Sunda, dan Mandarin. Beberapa pihak, antara lain guru Hoge Burger School di Serang, Padang Panjang, dan Fort de Kock telah menyatakan penolakan 
mereka atas kebijakan itu (Koemandang Djawi, 20 Februari 1919).

Kebijakan lain di bidang bahasa adalah penerapan bahasa Melayu resmi. Langkah ini dilakukan dengan mengikuti pola ejaan yang disebut Bahasa Melajoe Dines (Dienst Maleisch), yaitu bahasa Melayu yang biasa diajarkan dan digunakan dalam perkumpulan, kongres, dan dalam surat kabar Melayu. Pembakuan bahasa Melayu akan memudahkan proses pendidikan di sekolah-sekolah. Namun demikian, langkah ini tentu akan dirasakan berat bagi orang Jawa karena penduduk yang berbahasa Jawa paling banyak. Kebijakan ini bahkan dapat dianggap sebagai belenggu bagi kebudayaan Jawa. Dalam kaitan dengan kebijakan tentang Bahasa Melayu, disebutkan bahwa Staat Commissie telah memberi nasihat kepada Minister van Binnenlandsche Zaken dan Minister van Kolonie bahwa untuk memenuhi keperluan penduduk Tanah Hindia, bahasa Melayu harus diajarkan di sekolah menengah yang akan didirikan oleh pemerintah di Hindia (Jawa) (Koemandang Djawi, 10 Februari 1919).

Kuatnya arus budaya Barat juga berpengaruh pada bidang sastra. Pada awal abad XX pengaruh genre novel, cerita pendek, dan esai Barat sangat dominan terhadap sastra Jawa (Ras, 1985: 8; Wal, 2001: 12). Pengaruh itu menumbuhkan dua hal yang berbeda. Pertama, genre sastra baru itu menggeser sastra Jawa lama. Pada umumnya sastra Jawa lama berbentuk tembang yang biasanya diciptakan oleh seorang pujangga yang berstatus sebagai abdi raja. Dengan demikian, sastra Jawa lama berfungsi untuk melegitimasi kekuasaan (Berg, 1985). Kedua, genre baru itu memungkinkan munculnya pengarang dari berbagai lapisan sosial. Dengan demikian, sastra Jawa kemudian berfungsi sebagai ekspresi sosial. Selanjutnya dapat dilihat misalnya sebagai model sosialisasi nilai tentang kehidupan dunia istana Jawa terhadap anak-anak di lingkungan wilayah kekuasaan Mangkunegaran seperti tampak dalam karangan Yosowidagdo, Botjah Mangkoenegaran. Muncul pula ekspresi penolakan terhadap sistem perkawinan paksa yang diungkapkan oleh R.M. Sulardi dalam Serat Rijanto. Gambaran suasana Mangkunegaran yang lain ditampilkan oleh Sastradiharja dalam novel Soewarsa Warsijah. Dalam novel ini ditampilkan tentang persoalan seputar derajat sosial dalam perkawinan, selain sifat kesetiaan dan kegigihan wanita pedesaan yang sangat kontras dengan kalangan bangsawan kota yang lebih mengandalkan segi kepangkatan. Selain itu berkembang pula cerita perjalanan. Untuk jenis ini, cerita perjalanan karangan Raden Mas Harya Soerjosoeparto yang berjudul Serat Cariyos Kekesahan saking Tanah Jawi dhateng Nagari Walandi banyak disukai di Surakarta pada awal abad ke-20. Dalam perkembangan, genre baru telah memungkinkan sastra Jawa berkembang pesat menjadi bacaan popular pada dekade 1920 dan 1930.

Pengaruh Eropa juga muncul pada bidang busana dan tatacara istana Jawa. Di Mangkunegaran, pengaruh ini tampak sekali sejak periode pemerintahan Mangkunegara VI yang mulai memerintah pada 1896. Pengaruh itu mulai tampak semenjak meninggalnya ibu suri yaitu Kangjeng Raden Ayu Adipati Mangkunegara IV. Pembaharuan yang pertama terlihat pada era Mangkunegara VI adalah pada Balepeni - sebuah ruangan yang digunakan untuk menjalankan pemerintahan istana Mangkunegaran - yang tampak lebih berwibawa setelah lantainya diperbaiki dengan komposisi lantai dari tegel bermotif bunga. Setelah itu muncul tatacara baru yang memperlihatkan sebuah perubahan radikal di istana yaitu diterapkannya aturan duduk sejajar dengan memakai kursi. Aturan lama mengenai perhormatan dengan cara menyembah sambil jongkok juga dihilangkan. Menurut aturan baru, sembah hanya dilakukan pada awal dan akhir pertemuan (Djawa, 1924).

Di kalangan Legiun Mangkunegaran, penampilan prajurit pribumi mengalami banyak perubahan. Menurut Mangkunegara VI, untuk menambah efektivitas gerak maka penampilan prajurit pribumi Legiun Mangkunegaran perlu diubah. Sejak Mangkunegara VI, prajurit legiun mulai diberi penampilan Eropa yang baru sama sekali, misalnya prajurit harus memotong rambut pendek dan memakai topi, tidak lagi memakai udheng-ikat kepala tradisional. Selain itu, untuk menambah kesigapan bergerak prajurit 
mulai memakai sepatu. Untuk penampilan model rambut pendek, Mangkunegara VI sendiri yang memberi contoh. Ia mengubah penampilannya dengan rambut pendek rapi tanpa topi sejak ia memotong rambutnya di tempat potong rambut milik orang Perancis bernama Pianelli pada 24 Oktober 1911. ${ }^{12}$ Mangkunegara VI merupakan elite pribumi pertama dengan penampilan potongan rambut pendek. Dengan penampilan-nya yang baru itu, kalangan abdi istana diizinkan untuk tidak lagi memakai kuluk, kampuh, dan sikepan, kecuali saat upacara khusus (Rouffaer, 1905: 604; Dalyana: 39).

\section{POLITIK IDENTITAS}

Praktik kanonisasi pada akhirnya menggulirkan suasana kaku dalam bentuk politik identitas, suatu kebijakan yang mengarah pada identifikasi sosial dan ras di dalam masyarakat. Kondisi ini tampak sekali pada suasana di ruang publik. Sebuah karya sastra berjudul Kirti Ndjoendjoeng Dradjat menggambarkan praktik itu dalam ungkapan yang tegas seorang kondektur kereta api dari Balapan menuju Klaten: "Boeri, Boeri, Wong Djawa Boeri “ (Belakang, Belakang, Orang Jawa tempatnya di Belakang), menunjuk pada tempat mereka yang sesungguhnya yaitu di gerbong kelas 3. Fakta itu menegaskan bahwa di Surakarta sejak munculnya alat transportasi kereta api telah menempatkan orang pribumi pada kelas rendah, sementara kelas istimewa hanya dimiliki oleh komunitas kulit putih dan Cina. Klasifikasi ras terkait fasilitas publik itu semakin jelas seperti tampak dari tulisan yang tertera pada karcis kereta api: "Wong Djawa Ora Kanggo Sneltrein” (Koemandang Djawi, 5 November 1917).

Diskriminasi terhadap komunitas pribumi Jawa juga dapat dilihat pada peraturan baru tentang vrijbiljet (tiket bebas) kereta api yang dibuat oleh SS pada 1916. Sebelum peraturan baru itu muncul, pegawai pribumi memperoleh fasilitas vrijbiljet. Setiap tahun mereka mendapat 12 kartu bebas untuk kereta kelas 3. Kekecualian terjadi pada November 1915 ketika pegawai kelas 1 yang sudah bergaji $f$. 66 memperoleh tempat duduk di kelas 2. Semua fasilitas itu berlaku untuk semua pegawai baik yang telah tercatat ataupun tidak (benoemd of onbenoemd). Fasilitas itu biasanya juga berlaku untuk semua anggota keluarga pegawai yang memperolehnya termasuk anak dan istrinya. Namun, sejak muncul peraturan baru itu, fasilitas lama tidak berlaku lagi. Dalam peraturan baru, fasilitas dibedakan untuk pegawai pribumi yang tercatat dan yang tidak tercatat. Selain itu fasilitas vrijbiljet menjadi lebih rumit lagi karena dibedakan menjadi tiga jenis yaitu Karcis Putih (kelas 3), Karcis Pribumi (kelas 3), dan Karcis Hijau (kelas 3). Karcis Putih hanya diberikan kepada pegawai pribumi yang terdaftar (inlander benoemd), yaitu pegawai kelas 2 yang gajinya telah mencapai $f .45$ atau lebih. Jenis karcis pribumi kelas 3 diberikan kepada semua pegawai pribumi. Dengan demikian semua pegawai pribumi yang terdaftar yang gajinya kurang dari f.45 termasuk yang memperoleh fasilitas ini. Demikian pula pegawai kelas 2, meskipun gajinya sebesar $f .66$ atau lebih dan terdaftar tidak memperoleh fasilitas kelas 2 melainkan hanya kartu bebas kelas 3. Banyak protes ditujukan pada kebijakan vrijbiljet baru ini, antara lain karena fasilitas ini hanya berlaku untuk pemegang hak vrijbiljet dan tidak mencakup keluarganya. Karcis itu juga dianggap kurang praktis karena harus disobek ujungnya setiap kali jalan, dan yang paling dipersoalkan adalah apakah kalangan pegawai Eropa juga mendapat perlakuan seperti ini. ${ }^{13}$

Realitas di atas tampaknya telah menimbulkan keraguan dan kekecewaan di kalangan komunitas Jawa terhadap sifat kejawaannya. Gambaran mengenai hal ini dapat dilihat pada tulisan seorang redaktur luar kota (buitengewoon redacteur) surat kabar Koemandang Djawi, R. Hadi, yang tinggal di Ngadirojo Temanggung. Dalam sebuah artikelnya yang berjudul "Pro \& Contra" ia mengungkapkan bahwa secara umum orang Jawa itu penuh kontradiksi. Pada satu sisi orang Jawa selalu dilihat sebagai bangsa yang sangat tinggi budayanya, namun pada sisi lain di manamana terjadi stigma negatif seperti: speciaal voor en vanwege de Javanen, di hotel ada Kamar Jawa, di kereta ada Kelas Moerah (untuk orang Jawa), di komidi (tenda) ada Kelas Kambing, dan di 
kapal baik Belanda maupun Lloyd ada Kamar Kraton; yang semua itu jelas menunjukkan di mana Kelas Jawa (Koemandang Djawi, 6 Juni 1919).

Rasa superioritas kulit putih semakin luas sampai memasuki dunia profesi sebagaimana tercermin dari ucapan van der Jagt, seorang asisten residen di Kebumen, dalam sebuah sidang Volksraad yang bernada merendahkan wartawan pribumi dengan sebutan Boemi Poetra Keloearan Sekolah Setalen. Tuduhan itu mengarah pada Abdul Muis dan Cipto Mangunkusuma yang selalu mengkritik kebijakan Volksraad. Pernyataan itu kiranya telah menunjukkan betapa hegemoni ras menjadi bias karena diucapkan oleh seorang anggota wakil rakyat. Hal itu sekaligus mencerminkan di mana posisi Volksraad sesungguhnya (Koemandang Djawi, 13 Januari 1919 ).

Sikap ketimpangan sosial ini semakin tampak dalam kehidupan sehari-hari. Sebuah berita dalam kolom Chabar Harian menceriterakan suatu kejadian kecelakaan di Klaten ketika seorang wanita pedagang pribumi tertabrak mobil yang dikendarai oleh dua orang kulit putih. Kejadian ini sempat diperiksa oleh polisi. Anehnya, orang kulit putih itu dibiarkan pergi sementara wanita pedagang dimarahi (Koemandang Djawi, 24 Februari 1919). Insiden ini setidaknya semakin memperkuat gambaran ketidakadilan dalam masyarakat kolonial yang mengutamakan privillege kalangan kulit putih.

Praktik politik identitas semakin lama semakin menciptakan dikotomi sosial yang tajam. Kalangan pribumi pun kemudian terseret ke arah sikap yang sulit dihindari. Dalam menyikapi reaksi berlebihan komunitas Eropa melalui surat kabar terhadap rencana pemogokan buruh pandhuis, kaum pribumi menjuluki surat kabar mereka sebagai "pers putih". ${ }^{14}$

Ungkapan yang paling menonjol menggambarkan politik identitas yang secara jelas merendahkan orang Jawa adalah gambar sampul buku Djalan ke Barat-Weg tot het Westen karangan Nieuwenhuis. Gambar sampul itu memperlihatkan seorang wanita pribumi
Jawa berkain batik sambil memegang buku sedang dibimbing oleh seorang wanita kulit putih untuk menapaki tangga menuju cahaya Peradaban Barat. Judul buku itu sendiri sudah cukup mewakili maksud kolonial bahwa kemajuan Jawa hanya mungkin dicapai sejauh melalui jalan pembaratan (lihat Gambar 2) (Groeneboer, 1998: 67, 55, 167).

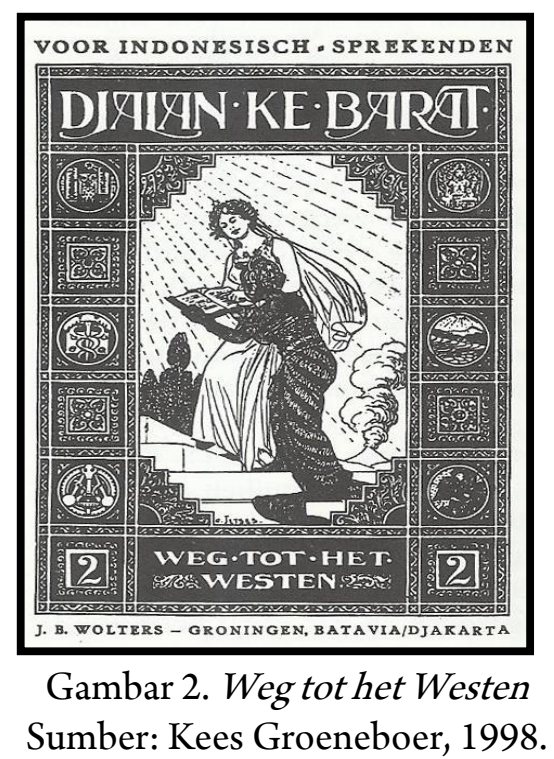

\section{KEGELISAHAN ATAS HILANGNYA IDENTITAS KOMUNITAS}

Kanonisasi budaya dan praktik politik identitas sebegitu jauh telah mengikis identitas Jawa. Hal ini telah menimbulkan kegelisahan di kalangan komunitas Jawa yang akhirnya diungkapkan dalam berbagai reaksi. Dalam kaitan ini bahasa Belanda yang secara sosial dianggap mempunyai nilai tinggi semakin dirasakan menjadi sumber kegelisahan utama yang berpotensi mengancam bagi etnis dan budaya Jawa di Surakarta (Groeneboer, 1998: 159). Ungkapan kecemasan itu dapat dilihat pada artikel berjudul "Bahasa Belanda dalam Kalangan Boemi Poetera”, yang ditulis oleh seorang pribumi yang menggunakan nama popular Witte Paraffine. Dalam artikel ini secara lugas diungkapkan betapa melalui pendidikan moderen bahasa Belanda telah menimbulkan dua hal baik itu kemajuan atau pun kemunduran. Bahasa Belanda dipandang telah semakin menimbulkan cara hidup seperti orang Eropa. Akan tetapi, pada sisi lain, pendidikan Barat ikut pula mendorong 
munculnya pergerakan kaum pribumi yang ingin memajukan Kaum Kromodongso dan Kaum Kromoningrat. Kecenderungan itu dapat dilihat pada banyaknya perhimpunan yang didirikan di mana-mana untuk mencapai kemajuan. Dengan demikian pengaruh Eropa terhadap kecenderungan upaya pendirian perhimpunan itu telah melahirkan gaya hidup baru di kalangan pribumi. Sebaliknya, perkembangan bahasa Belanda juga semakin dirasakan membuat lemahnya kebudayaan Jawa oleh komunitas pribumi, karena akibat penilaian yang berlebihan atas bahasa asing itu kemudian menyebabkan pelajaran bahasa Kawi tidak diajarkan lagi di sekolah. Sementara di sisi lain sumber kebudayaan Jawa sebelumnya banyak ditulis dengan huruf Kawi, sehingga ketika media budaya itu tidak dipakai lagi maka pengetahuan Jawa pun kemungkinan akan semakin cepat hilang. Hal yang sama juga dialami dalam hal pengetahuan tentang tembang (pantun Jawa) yang ketika dibaca biasanya diiringi dengan gamelan. Ketika tembang tidak lagi diajarkan maka bukan saja seni itu yang akan punah, gamelan pun juga akan mengalami hal yang sama. Huruf Jawa pun semakin hilang seiring dengan diterbitkannya Kitab Bacaan Umum yang berhuruf Latin, seperti tampak pada Gambar 2 (Koemandang Djawi, 15 Oktober 1917).

Rupanya reaksi atas pengaruh asing terhadap unsur-unsur Jawa oleh kalangan pribumi sendiri ditanggapi secara berbeda-beda. Seorang kolumnis di koran Koemandang Djawi yang menamakan diri Toean Djawi Moedo mengungkapkan keluhan betapa mempelajari bahasa asing baik Belanda maupun Melayu sungguh membuang-buang waktu, lebih baik mempelajari ilmu yang berguna bagi etnis Jawa. Toean Djawi Moedo mendapat argumentasi baru yang berisi pandangan bahwa bahasa itu terikat menjadi satu dengan bangsanya, begitu pun dengan derajatnya tergantung pada bangsanya. Jika derajat bangsa Jawa masih rendah, tidak mengherankan jika bahasa Jawa belum mendapatkan penghargaan yang pantas. Nanti, jika sudah ada banyak pelayar Jawa, kapitalis Jawa, saudagar Jawa yang membawa kapalnya sendiri, tidak menjadi budak orang lain, bahasa Jawa dan apa pun yang terkait dengan Jawa akan dihargai. Pada saat itu bangsa Jawa dapat mengembangkan bahasa Jawa. Bahasa Melayu juga penting karena pada kenyataannya bahasa ini digunakan sebagai bahasa pergaulan, pertemuan, dan bahasa tertulis birokrasi (Koemandang Djawi, 3 Desember 1917).

Pada bagian lain di Vorstenlanden muncul kritik tajam terhadap anggapan bahwa peranan pemerintah Belanda di bidang pendidikan merupakan limpahan berkah kaum kulit putih. Kritik ini memang bertolak belakang dengan dugaan sebelumnya bahwa orang kulit putih adalah inisiatif dari segala perkembangan pendidikan di Jawa ketika pribumi hanya pasif dan tidak memperhatikannya sama sekali. Namun, data yang dimiliki A. Muhlenfeld sungguh mengejutkan dan sangat beralasan jika ia mengkritik kebijakan mengenai pendidikan Belanda yang timpang khususnya di Vorstenlanden. Muhlenfeld mengungkapkan bahwa tingkat kemampuan membaca dan menulis penduduk di Jawa mencapai 14 orang per 1000 penduduk. Namun, yang mengejutkan adalah perbandingan antara kondisi Residensi Surakarta dan Residensi Madiun yang mencapai 23 dan 24 untuk 1000 penduduk. Daerah yang dianggap rendah tingkat kemampuan membaca dan menulisnya adalah Residensi Batavia dan Madura yang hanya mencapai 9 dan 6 orang dari 1000 penduduk. Jika di Kota Batavia tidak dihitung termasuk orang asing barangkali angkanya hanya 6 dari 1000 penduduk. Di Wilayah Vorstenlanden yang meliputi Yogyakarta dan Surakarta diperoleh catatan mengenai tingkat literasi yang cukup tinggi yaitu mencapai 14 dan 9 persen dari seluruh jumlah penduduk. Tingkat kemajuan di Vorstenlanden dianggap masuk akal karena menurut Muhlenfeld kedua kota itu merupakan tempat orang Jawa asli yang mempunyai sejarah literasi yang panjang. Anehnya, tingginya angka tingkat literasi penduduk Vorstenlanden itu tidak identik dengan banyaknya fasilitas pendidikan seperti adanya sekolah yang didirikan oleh gubernemen. Tingkat literasi yang tinggi di Vorstenlanden terjadi karena besarnya peranan pemerintah tradisional yang sejak lama mementingkan peningkatan kemampuan literasi. 
Menjadi jelas bahwa sesungguhnya munculnya standar bahasa Belanda di Vorstenlanden bukan merupakan sumbangan yang dianggap penting secara substantif bagi pribumi, karena materi pendidikan pribumi sendiri sesungguhnya telah memadahi (Koemandang Djawi, 8 Oktober 1917).

Uraian di atas menunjukkan betapa kebijakan pendidikan pemerintah sangat timpang antara wilayah gubernemen dan Vorstenlanden. Oleh karena itu, munculnya isu tentang penghapusan Vorstenlanden yang telah merebak pada awal abad XX dipandang oleh komunitas Jawa sebagai sikap arogansi kolonial. Itu sebabnya munculnya penafsiran baru terhadap makna Zelfbestuur menjadi sangat beralasan.

Selain soal bahasa Belanda dan Melayu, bentuk kegelisahan lain akibat kanonisasi adalah penolakan terhadap anjuran penggunaan pakaian resmi model Eropa berupa jas, celana, dan sepatu. Anjuran itu telah berhasil diterapkan di Temanggung, sebuah kota yang termasuk bagian dari wilayah gubernemen. Atas praktik penggunaan pakaian resmi baru bagi pegawai pamong praja itu muncul kritik pedas dari orang yang memakai nama Sorjosoemirat. Menurutnya, pakaian tradisional sesungguhnya lebih tepat dipakai oleh pejabat lokal karena mencerminkan karakter Jawa. Namun, di kalangan pejabat di wilayah gubernemen muncul pendapat lain yaitu bahwa berpakaian cara Barat merupakan upaya untuk mengangkat derajat orang Jawa supaya tampak pantas dan mulia. Pendapat yang dilontarkan oleh R.H. Notopoero itu tampak sekali mewakili pandangan tentang penggunaan pakaian Barat di wilayah gubernemen (Koemandang Djawi, 3 Desember 1917).

Praktik kanonisasi tidak hanya menimbulkan reaksi lokal yang biasa, tetapi telah memunculkan rivalitas antara komunitas kulit putih dan pribumi Jawa. Rivalitas itu muncul terutama pada pertengahan dekade kedua abad XX akibat dari banyaknya surat kabar berbahasa Belanda yang selalu merendahkan kaum pribumi. Hal ini semakin menunjukkan betapa suasana kolonial Belanda sungguh telah terbentuk secara mantap di Jawa yang jauh berbeda dari kultur Indis abad XIX. Hal ini bahkan sempat memunculkan anjuran lewat surat kabar lokal supaya kaum pribumi menjauhi bacaan berbahasa Belanda yang isinya selalu menghasut kaum pribumi (Koemandang Djawi, 17 Desember 1917).

Suasana kolonial di Surakarta dalam perkembangan melahirkan sikap baru terhadap berbagai aksi kulit putih. Terhadap pandangan Van der Jagt yang muncul di Volksraad yang telah merendahkan kaum pribumi tidak cukup dihadapi secara responsif saja, melainkan harus dengan cara baru yaitu langkah revolusioner (Koemandang Djawi, 3 Desember 1919 dan 27 Oktober 1919).

Resistensi terhadap dominasi kolonial Belanda semakin keras karena dominasi itu telah menyentuh hal-hal yang sifatnya prinsip seperti soal perkawinan campur dan rasa kemanusiaan orang Jawa. Berita tentang perkawinan campur itu muncul dari surat kabar Sarotama, sebuah sumber berita yang berhaluan keagamaan di Surakarta. Berita itu menekankan bahwa praktik perkawinan campur antara laki-laki kulit putih dan wanita pribumi Islam sangat dikeluhkan terutama dalam konteks pandangan ke depan, apakah praktik ini kemudian akan menjadi suatu kebiasaan? Jika betul, betapa rendahnya kalangan pribumi Islam karena dalam praktik seorang pribumi tidak mempunyai hak apa pun. Bahkan, anak hasil dari perkawinan itu akan dianggap sebagai warga Belanda. Menurut kalangan Islam, cara demikian bukan merupakan suatu bentuk perkawinan suci, mengingat gaya hidup totok dan Indo sangat bertentangan dengan kaidah Islam (Sarotama, 9 Maret 1916).

Pada bagian lain, apa yang didengungkan oleh pemerintah kolonial bahwa pendidikan Barat dipandang sebagai bentuk persamaan, oleh lapisan bawah pribumi dianggap sebagai suatu kekeliruan. Menurut mereka, bentuk pendidikan yang tepat adalah yang menurut ajaran Jawa kuna yaitu lebih mengutamakan sisi kemanusiaan dengan cara membangun sikap mampu menempatkan diri terhadap orang lain yang disebut sikap tepo-tepo. Oleh karena itu, tidak pada tempatnya jika kaum rendah hanya melihat setiap kebijakan pemerintah. Rakyat jelata pun berhak dengan caranya sendiri 
menyuarakan tuntutannya untuk membangun kondisi tepo-tepo atau sama rasa sama rata (Tjoendamani, 5 November 1918).

\section{SIMPULAN}

Kebijakan kanonisasi pada awalnya bertujuan untuk menerapkan nilai-nilai Eropa di Hindia Belanda. Akan tetapi, dalam praktik, Eropanisasi itu telah melahirkan masyarakat kolonial yang menimbulkan kegelisahan terutama bagi komunitas Indo dan pribumi Jawa di Surakarta. Kedua komunitas itu merasa gelisah karena identitas mereka sebagai bagian dari masyarakat Indis telah terkikis. Praktik kanonisasi itu telah mengundang reaksi dari kedua komunitas itu yang ingin mengambil langkah untuk menemukan kembali identitas mereka.

\section{CATATAN}

${ }^{1}$ Dengan perhitungan bahwa tingginya jumlah penduduk wanita per 1000 orang dianggap cukup besar, sementara Surakarta termasuk dalam kategori enam kota besar di Jawa, maka data Creutzberg ini mengindikasikan bahwa jumlah wanita pendatang baru di Surakarta juga semakin bertambah. Kota yang termasuk enam kota besar di Jawa pada awal abad XX adalah Batavia, Bandung, Semarang, Yogyakarta, Surakarta, dan Surabaya. Tentang hal ini lihat Elsbeth Locher-Scholten (2005), hlm. 227. Dalam sumber lain disebutkan bahwa kategori kota besar didasarkan pada perhitungan Komisi Pembangunan Kota (Stadsvormings-commissie) yaitu dilihat dari jumlah penduduk kota yang melebihi 100.000 orang. Pada 1905, dibandingkan dengan jumlah penduduk seluruh Jawa, persentase keenam kota di atas mencapai 2,21\%. Dari keenam kota itu, empat di antaranya yaitu Batavia, Bandung, Semarang, Surabaya dikategorikan sebagai snelgroeiers karena percepatan pertumbuhan penduduknya yang berlipat ganda dalam 10-20 tahun. Sementara itu, Yogyakarta dan Surakarta termasuk kategori groeier karena percepatan pertumbuhan penduduknya baru berlipat ganda setelah mencapai kurun 25-40 tahun. Natanegara, "Membangoen Kotta”, Hoedyana-Wara, Juli 1941, hlm. 39-40.

${ }^{2}$ Lebih lanjut tentang hal ini periksa "Algemeene Verslag van Residentie Soerakarta over het jaar 1888”, Bundel Solo No. 388, ANRI. Dalam sumber lain disebutkan bahwa nama Imam Sampurno sebelumnya adalah Imam Rejo. Lihat Pengetan Lelampahanipun Kangjeng Gusti Pangeran Adipati Aryo Mangkunagoro IV, V, VI dumugi Ingkang Kaping VII (Semarang: Departemen Pendidikan dan Kebudayaan, 1984), hlm. 43.

${ }^{3}$ Meskipun telah berdiri Landraad, penguasa tradisional di Surakarta masih menanggung biaya operasional lembaga pengadilan Belanda ini. Pengeluaran untuk gaji pimpinan, juru tulis, jaksa, polisi pengadilan, dan saksi ditanggung oleh Kasunanan, Mangkunegaran dan Karesidenan (Narpawandawa, 3 Januari 1932).

${ }^{4}$ Pengadilan pribumi pada akhir abad XIX masih berwibawa. Pengadilan Pradata Kasunanan, misalnya, pada 1884 mengadili kasus pembunuhan yang menelan korban delapan orang, tujuh di antaranya dari afdeeling Wonogiri dan satu dari Boyolali. Pada tahun tersebut lembaga ini juga mengadili kasus begal dan kecu serta 64 kasus pembakaran rumah yang terjadi pada satu tahun sebelumnya. Pada 1885 tindak kriminal seperti begal, pembakaran rumah, dan pencurian hewan semakin marak dan merata di afdeeling Surakarta, Klaten, Wonogiri, Sragen, dan Boyolali. Kasus kriminal yang semakin meningkat ini mendorong munculnya usul tentang reorganisasi keamanan, karena tanggung jawab patih atas ketertiban dan keamanan mulai dipertanyakan. Bandingkan: Algemeen Verslag der Residentie Soerakarta over het jaar 1884, Bundel Solo No 388, ANRI; dan Algemeen Verslag der Residentie Soerakarta over het jaar 1885, Bundel Solo No. 389, ANRI.

${ }^{5}$ Fungsi pengadilan baru dapat dilihat pada penanganan kasus berikut. Pertama, kasus kecu yang melibatkan R.M. van Son, yang berdasar Keputusan Pemerintah 9 November 1910 No. 5 dibuang ke luar Jawa. Kedua, pada 1913 perusuh di Klaten yang bernama Wongsosentono oleh pengadilan yang dipimpin oleh Asisten Residen Harlof, berdasar Keputusan Pemerintah 12 Desember 1913, dihukum buang ke Merauke. Bandingkan: "Pengadilan Dalem ing Praja Surakarta Saderengipun Taun 1903”, Kabar Paprentahan, koleksi Reksopustoko Mangkunegaran No. B262, hlm. 88. Lihat juga MvO van Wijk, 1916, hlm. 61.

${ }^{6}$ Uraian yang terperinci untuk masing-masing peraturan dapat dibaca dalam Rooi-Reglement (1894). Hal Berdiriken Roemah Sabageinja di Dalem Kota Soerakarta; Reglement dari Koeadjibannja Kepala-Kepala Desa(1906); dan Reglement Politie (1907).

${ }^{7}$ Bandingkan $\mathrm{MvO}$ van Wijk, hlm. 4 dan $\mathrm{MvO}$ Sollewijn Gelpke, hlm. 9. 
${ }^{8}$ Pemikiran van Wijk ini jelas mencerminkan rasa superioritas kultur baru Belanda atas pribumi Jawa. van Wijk sebetulnya menyadari adanya indikasi bahwa penguasa keraton Surakarta akan selalu mencoba memerintah tanpa pengaruh Eropa. Dalam kaitan ini setidaknya ia telah belajar dari akibat fatal yang pernah menimpa pendahulunya yaitu Residen Burnabij Lauthier (1890-1894) yang meninggal mendadak terkena racun karena ia secara arogan berani menduduki singgasana raja yang kosong sebelum ditetapkan dan diangkatnya raja baru sepeninggal Pakubuwana IX pada 17 Maret 1893. Karena pengaruh Eropa dapat diterapkan untuk keraton Yogyakarta, van Wijk merasa jengkel ketika mengalami kesulitan untuk menerapkan hal serupa pada keraton Surakarta dalam bentuk pembukuan moderen atas keuangan keraton yang dilakukan oleh akuntan Eropa. van Wijk menunjukkan kekesalannya dalam laporannya melalui ucapan: "Semua pembicaraan tidak banyak memberikan hasil karena kebodohan sunan". $M v O$ van Wijk, hlm. 23-24. Mengenai kasus Burnabij Lauthier, baca Sorgdrager (1936).

${ }^{9}$ Mengenai pelaksanaan penghapusan apanage di Mangkunegaran, baca Rijksblad Mangkoenagaran 1917 No. 34; Pranatan Betreffende de opheffing der apanage van de poetro's in de plaats waarvoor een mandelijksch tractement wordt uitgekeerd; dan Rijksblad Mangkoenagaran 1917 No. 35 Gewijzigd. ${ }^{10}$ Rijksblad Soerakarta 1917 No.49, Verordening betreffende de opheffing van apanages, gelegen in de districten Sragen, Masaran, Gemolong, Gondang en Gesi (Afdeeling Sragen).

${ }^{11}$ Periksa lebih lanjut Rijksblad Soerakarta 1917 No. 33, Regeling betreffende de verdeeling in de gemeenten van het Rijk Soerakarta, dan Rijksblad Soerakarta 1917No. 43 Regeling omtrent de desahoofden en de overig leden van het desabestuur in het Rijk Soerakarta.

${ }^{12}$ Isu tentang penghapusan Vorstenlanden memang bukan omong kosong. Dalam laporannya van Wijk mengemukakan bahwa ia diminta oleh Gubernur Jenderal van Heutz untuk memberitahu sunan bahwa keraton Surakarta akan tetap dipertahankan sejauh dibenahi dan dikelola secara moderen. Hal ini berarti bahwa Vorstenlanden kemungkinan akan mengalami nasib lebih buruk jika selalu menolak Eropanisasi. Isu Vorstenlanden juga memunculkan konsekuensi penafsiran baru tentang Zelfbestuur yang mulai dikaitkan dengan pemerintahan mandiri yang bebas dari pengaruh asing. Bandingkan $\mathrm{MvO}$ van Wijk, hlm. 23-24 dan $M v O$ Sollewijn Gelpke, hlm.30.
${ }^{13}$ Pengetan Lelampahanipun Kangjeng Gusti Pangeran Adipati Aryo Mangkunagoro IV, V, VI, dumugi Kaping VII yang telah diterbitkan oleh Departemen Pendidikan dan Kebudayaan RI.

${ }^{14}$ Pihak pribumi yang melakukan protes kebanyakan berasal dari kaum pribumi kelas 2 yang bergaji $f .66$ atau lebih. Baca "Atoeran SS Memoesingkan Kepala”, Sarotama No. 10, Kamis, 9 Maret 1916.

${ }^{15}$ Penyebutan itu berkaitan dengan rencana pemogokan pegawai pandhuis, tetapi tidak jadi. Rupanya langkah pemogokan yang akan dilakukan oleh PPPB ini telah banyak dikritik oleh kalangan Eropa melalui pers, sehingga koran penyebar kritik itu disebut sebagai pers putih. Penulis M. Sjarief melalui tulisannya sangat mencela kritik dari pers putih itu. Lihat "Orang jang Tertindas Biar Hantjoer Leboer”, Koemandang Djawi, 10 Maret 1919.

\section{REFERENSI}

"Pengadilan Dalem ing Praja Surakarta Saderengipun Taun 1903”, Kabar Paprentahan, koleksi Reksopustoko Mangkunegaran No. B262.

ANRI, "Algemeen Verslag der Residentie Soerakarta over het jaar 1884”, Bundel Solo No. 388 .

ANRI, "Algemeen Verslag der Residentie Soerakarta over het jaar 1885”, Bundel Solo No. 389.

ANRI, "Algemeen Verslag van Residentie Soerakarta over het jaar 1886”, Bundel Solo No. 388 .

ANRI, “Algemeene Verslag van Residentie Soerakarta over het jaar 1888" Bundel Solo No. 388

Berg, C.C. (1985). Penulisan Sejarah Jawa. Jakarta: Bhratara Karya Aksara.

Creutzberg, Pieter (1987). Sejarah Statistik Ekonomi Indonesia. Jakarta: Yayasan Obor Indonesia.

Dalyana (1939). Het Staatrecht van het Mangkoenegorosche Rijks. (Bijlage IV). Soerakarta: Reksa Poestaka

Elsbeth, Locher Scholten, "Pakaian musim panas dan makanan kaleng: perempuan Eropa dan gaya hidup Barat di Hindia 19001942" dalam Henk Schulte Nordholt (ed). (2005). Outward Appearances: Trend, Identitas, Kepentingan. Yogyakarta: LKiS. 
Groeneboer, Kees (1998). Gateway to the West the Dutch Language in Colonial Indonesia 1600-1950 A history of language policy. Amsterdam: Amsterdam University Press.

Hoedyana-Wara, Juli 1941.

Koemandang Djawi, 10 Februari 1919.

Koemandang Djawi, 10 Maret 1919.

Koemandang Djawi, 13 Januari 1919.

Koemandang Djawi, 15 Oktober 1917.

Koemandang Djawi, 16 Juni 1919.

Koemandang Djawi, 17 Desember 1917.

Koemandang Djawi, 20 Februari 1919.

Koemandang Djawi, 20 Januari 1919.

Koemandang Djawi, 20 Oktober 1919

Koemandang Djawi, 24 Februari 1919.

Koemandang Djawi, 27 Oktober 1919.

Koemandang Djawi, 3 Desember 1917.

Koemandang Djawi, 5 November 1917.

Koemandang Djawi, 8 Oktober 1917.

Mangkoenagara VI. Djawa, Vol. XV (1924).

MvO Harloff, 1922.

MvO Sollewijn Gelpke, 1918.

MvO van Wijk, 1916.

Narpawandawa, 3 Januari 1932

Pengetan Lelampahanipun Kangjeng Gusti Pangeran Adipati Aryo Mangkunagoro IV, V, VI dumugi Ingkang Kaping VII (Semarang: Departemen Pendidikan dan Kebudayaan, 1984).

Ras, J.J. (1985). Bunga Rampai Sastra Jawa Mutakhir.Jakarta : Grafitipers.

Reglement dari Koeadjibannja Kepala-Kepala Desa (1906). Soerakrta: Albrecht Rusche $\&$ Co.

Reglement Politie (1907). Soerakarta: Albrecht Rusche \& Co.

Rijksblad Mangkoenagaran 1917 No. 34.

Rijksblad Soerakarta 1917 No. 33.

Rijksblad Soerakarta 1917 No. 43.

Rijksblad Soerakarta 1917 No. 49.

Rijksblad Soerakarta 1917 No. 49.

Rooi-Reglement (1894). Hal Berdiriken

Roemah Sabageinja di Dalem Kota Soerakarta Soerakarta: Albrecht \& Rusche.

Rouffaer, G.P. (1905). Vorstenlanden. Encyclopaedie van Nederlandsch-Indie. 'S-Gravenhage: Martinus Nijhoff.

Sarotama, 9 Maret 1916.
Sorgdrager, P. (1936). Gespreken met den Pangeran. Poerwokerto: De Boer.

Taylor, Jean Gelman (2009). Kehidupan Sosial di Batavia. Jakarta: Masup Jakarta.

Tjoendamani, 5 November 1918.

Van der Meijden, Catenius (1908). Ons Huis in Indies. Semarang: Masman \& Stroink.

Wal, S.L. van der (2001). Kenang-Kenangan Pangrehpraja Belanda 1920-1942. Jakarta: Djambatan. 